\title{
Including sediment in European River Basin Management Plans: twenty years of work by SedNet
}

\author{
Jos Brils ${ }^{1}$ (D) \\ Received: 26 May 2020 / Accepted: 13 September 2020 / Published online: 17 September 2020 \\ (C) The Author(s) 2020
}

\begin{abstract}
Purpose This paper describes the efforts made by SedNet - the European Sediment Network-to generate attention for the inclusion of sediment in River Basin Management Plans (RBMPs) under the European Water Framework Directive (WFD). Materials and methods The SedNet response to key WFD implementation events is described using the "three-streams and windows-of-opportunities model" published by John Kingdon in 1995.

Results and discussion SedNet was initially a response to the realization that the WFD — which came into force in 2000 - largely neglected sediment. For SedNet, it was clear from the beginning that the WFD objectives can be achieved only if sediment is included in RBMPs. The SedNet efforts inspired the establishment of a sediment management concept for the Elbe river basin. That concept was used as a basis for the full inclusion of sediment in the second Elbe RBMP (2015-2021). SedNet experts are currently involved in the drafting of the WFD Common Implementation Strategy (CIS) sediment document which will be completed in 2021 and that will provide guidance about how to include sediment in RBMPs.

Conclusions Since 2000, SedNet has persistently drawn attention to the need to include sediment in RBMPs. However, it was not until 2015 that the Elbe became the first European river basin to include sediment management fully in their RBMP. The 2021 WFD CIS sediment document and the focus on sediment in the Water Fitness Check in 2019 make it significantly more likely that the sediment will be included in the updates of WFD RBMPs in the near future.
\end{abstract}

Keywords Sediment $\cdot$ Sediment management $\cdot$ Water Framework Directive $\cdot$ River Basin Management Plans $\cdot$ SedNet

\section{Introduction}

The turn of the century proved to be a very important time for sediment and sediment management. It marked the launch of the first issue (in March 2001) of the Journal of Soils and Sediments (Owens and $\mathrm{Xu}$ 2020), the European Water Framework Directive (EC 2000) came into force in the year 2000, and the European Sediment Network, SedNet, was established in the same year (Gandrass et al. 2000). All these initiatives have been important for sediment and sediment management, and all of them are still very much alive and kicking twenty years later.

The SedNet objectives are to ensure the inclusion of sediment issues and knowledge in European strategies in order to

\section{Responsible editor: Marc Babut}

Jos Brils

jos.brils@deltares.nl

1 Deltares, Utrecht, Netherlands support the achievement of good environmental status and to develop new tools for sediment management. SedNet welcomes anyone to share and cooperate on the achievement of this mission, and it therefore brings together sediment professionals from science, government, management, nongovernmental organizations (NGOs), consultancy, and industry. SedNet interacts with a range of networks and organizations, especially in Europe, that operate at the national or international levels and focus on sediment, soil, and water and in fields such as science, policy, management, industry, and education. The focus is on all sediment quality and quantity issues - and their impact on ecosystem functioningranging from fresh water at the local and river basin scales to estuarine and marine sediments. SedNet is registered as an NGO in the European Union (EU) Transparency Register under identification number 869733426891-601. More details, including a library with all SedNet and other sediment management documents published since 2000, are available publicly and free of charge from the SedNet website, www. sednet.org. 
As explained by Owens and Xu (2020) in their Journal of Soils and Sediments (JSS) editorial, the serious lack of focus on sediment issues in the European Water Framework Directive (Förstner 2002) was one of the factors that led to the establishment of SedNet. JSS was the "associated journal" of SedNet, and, during the early years of the journal, there was considerable interaction between SedNet and JSS, including numerous editorials, commentaries, and research articles (Brils 2001, 2002a, b, 2003a, b, 2004a, b, 2005a, b; SedNet 2002, 2003a, b, c, d; Brils and de Deckere 2003; Heise 2003; Köthe 2003; Barceló et al. 2004; Bortone et al. 2004; Heise et al. 2004; Owens et al. 2004; Vellinga 2004; Netzband 2004, 2007; Apitz and Heise 2005; Hollert et al. 2005). Although there was a strong connection between JSS and Europe and SedNet, the aim was also to establish the international standing of the journal on the basis of the membership of the editorial board and also by working as a "cooperating journal" with the International Union of Soil Sciences (IUSS) (Blum 2002). To mark this expanded scope, JSS dropped the formal and explicit association with SedNet, but the fruitful cooperation between the two is still going strong after twenty years.

This invited paper describes twenty years of work by SedNet to generate attention for the inclusion of sediment management in Water Framework Directive (WFD) River Basin Management Plans (RBMPs).

\section{Materials and methods}

This paper provides a chronological description of the WFD RBMPs drafting and implementation cycles and also describes the efforts made by SedNet and by two SedNet-inspired, cornerstone initiatives targeting the inclusion of sediment in these RBMPs. This paper covers the period since 2000 to date, and it looks forward to the near future of developments in WFD sediment management.

To describe these developments, this paper draws on Kingdon's three-streams and windows-of-opportunity model (Kingdon 1995). The model includes a problem, policy, and political stream (Fig. 1). "We conceive of three process streams flowing through the system - streams of problems, policies and politics. They are largely independent of one another, and each develops according to its own dynamics and rules. But at some critical junctures the three streams are joined, and the greatest policy changes grow out of that coupling of problems, policy proposals, and politics" (Kingdon 1995). Two key elements here are urgency and timing (Brils 2012). Problems raised under the problem stream have to be perceived by representatives of the policy and political streams as urgent. These representatives must realize that without the inclusion of sediment, the WFD goals will not be achieved. The assumption here is that representatives consider the achievement of the WFD goals to be urgent. The timing should also be right: as a "problem raiser," you must be there with your message when the window of opportunity opens for the transmission of that message to representatives in the policy and political streams.

In the problem stream, problems are raised, in this case "the WFD goals cannot be achieved without the inclusion of sediment in RBMPs." In the policy stream, policies are drafted to deal with the problems that need to be addressed, such as the "full inclusion of sediment in the drafted RBMPs to achieve to WFD objectives." In the political stream, the drafted policies are approved so as to mandate their implementation, in this case the "approval and mandated start of the implementation of a RBMP that includes sediment management."

When two or all three streams converge, a window of opportunity opens for change. Converging problem and policy streams and policy and political streams, respectively, open a "problem window" or a "political window." The convergence of three streams opens a "policy window" which provides the best opportunity for change. In relation to sediment management, this means a recognition that sediment management is crucial to achieve the WFD objectives (problem stream) and therefore that it is fully included in a RBMP (policy stream) which is politically approved and mandated for implementation (political stream).

\section{Results and discussion}

\subsection{Observed and anticipated windows of opportunity (2000-2027)}

The application of the Kingdon model results in the observation or expectation of the following windows for the inclusion of sediment in WFD RBMPs (Fig. 2):

- First political window (2009): The first RBMPs to be drafted received political approval, but the sediment management was not yet fully included in any of them.

- First problem window (2014): The SedNet-inspired sediment management concept of the ICPER (International Commission for the Protection of the Elbe River) was welcomed and used by the Elbe RBMP drafters.

- First policy window (2015): The RBMP drafted for the Elbe, with the full inclusion of sediment, was politically approved and its implementation began.

- Second problem window (2021): the WFD Common Implementation Strategy (CIS) sediment document on how to include sediment in RBMPs will be completed in 2021, and it is expected that it will be welcomed and used by the RBMP drafters.

- Second policy window (2021): The CIS sediment document will not be completed in time to serve 
Fig. 1 The Kingdon (1995) threestreams and windows-ofopportunity model

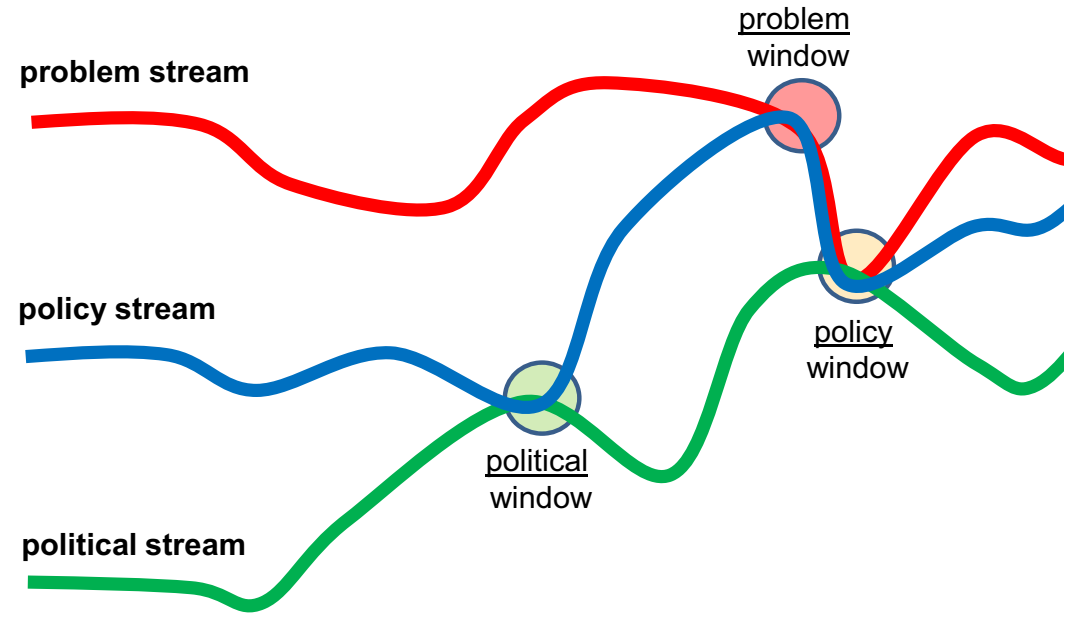

time as a basis for the drafting of the third round of RBMPs. That drafting process is reaching completion at present (mid-2020). It is unclear and therefore questionable if - with the exception of the Elbe-sediment management will be fully included in any RBMP.
- Third policy window (2027): The CIS sediment document will be completed in time to serve as a basis for the drafting of the fourth round of RBMPs. There are also a few other indicators - in addition to interest in the CIS sediment document - that there is a greater awareness in WFD circles of sediment management

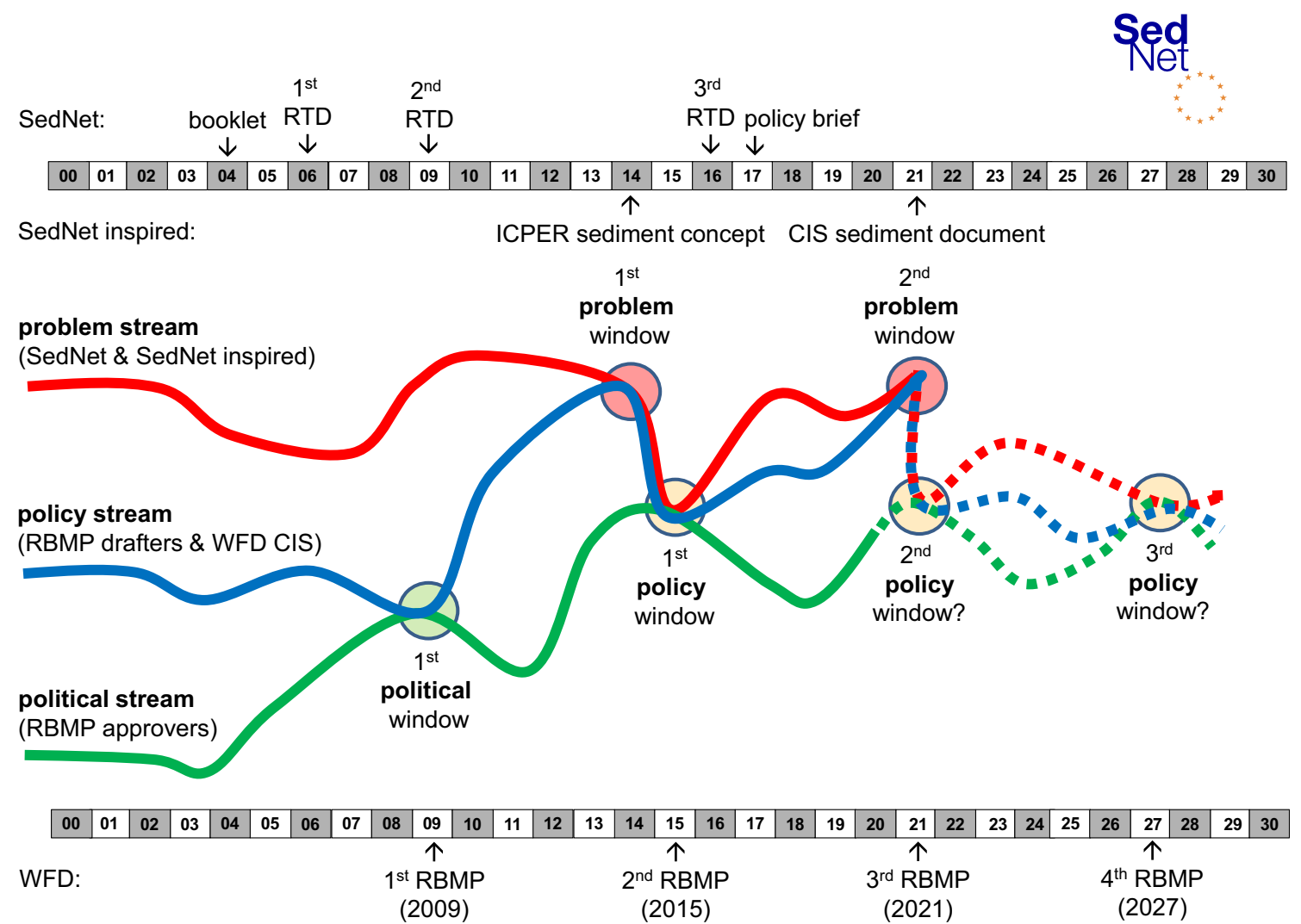

Fig. 2 Observed and anticipated windows of opportunity for the inclusion of sediment in WFD RBMPs (RTD round table discussion,

CIS Common Implementation Strategy, WFD Water Framework ICPER International Commission for the Protection of the Elbe River, 
and it is therefore likely that some other European river basins, in addition to the Elbe, will fully include sediment in their RBMPs by 2027.

The processes leading to the opening of these windows are described below.

\subsection{Towards the first political window (2000-2009)}

The legal text of the WFD (EC 2000), which has been in force since 2000, uses the word "sediment" on only eight occasions. On seven of those occasions, sediment is linked to quality (physico-chemical, pollutants, priority substances). The eighth is a reference to sediment quantity in which the WFD attributes "high status" to the hydromorphological quality element "river continuity": "The continuity of the river is not disturbed by anthropogenic activities and allows undisturbed migration of aquatic organisms and sediment transport" (EC 2000). Although sediment is mentioned, then the WFD does not specifically address sediment management. Those engaged in the drafting of the first round of WFD RBMPswith 2009 as the year in which implementation was plannedwere not urged to include sediment explicitly in those RBMPs.

The key message in the 2004 SedNet booklet Contaminated Sediments in European River Basins is that sediment is an essential, integral, and dynamic part of our river basins and that sediment management should be integrated in RBMPs in order to achieve the WFD objectives (Salomons and Brils 2004). This SedNet key message was transmitted to the WFD team leader - a representative of the policy stream-at the European Commission (EC) Directorate General Environment in Brussels in 2003. The WFD team leader understood the message, but his frank reply was that the WFD had just come into force and that it was more urgent to address other implementation issues rather than sediment (personal communication, J. Brils).

In the realization that sediment-related quantity and quality issues still played a relatively minor role in the WFD Common Implementation Strategy (CIS) process, SedNet decided to focus on providing scientific and user-oriented input for the WFD implementation phase, organizing a round table discussion on 22 and 23 April 2006 in Venice, Italy, under the title "Sediment management - an essential element of River Basin Management Plans" (SedNet 2007). The aim was to derive generic and specific recommendations for sediment management based on experiences in selected key river basins in the light of legal requirements, user needs, and scientific advice. The round table discussion brought together delegates from European river commissions, user groups, and scientists. The river basins represented were the Danube, Douro, Elbe, and Humber. The ongoing work on the River Rhine sediment management plan was presented by the chairman of the ad hoc working group on sediments of the International Commission for the Protection of the Rhine. The conclusion of the discussion was that achieving good ecological statusas required by the WFD - requires proper attention for sediment issues, with an awareness of natural variation and differences between river basins. It was therefore recommended that sediment management in terms of quality and quantity should receive due attention in WFD RBMPs and that any failure to include sediment management in the RBMPs should be justified. Furthermore, it was recommended that the EU should fund not only problem identification but also problemsolving processes. It was argued that sediment issues should be discussed between different Directorate Generals (DGs) in Brussels such as DG Environment, DG Transport, and DG Health (SedNet 2007).

The SedNet message did not have any impact at that time because the message was not delivered at the right moment (it was too early) and the problem was not yet perceived as urgent because the WFD did not specifically advocate the inclusion of sediment. Sediment management was therefore not included fully in any of the first round of RBMPs that began to be implemented in 2009.

\subsection{Towards the first problem and policy window (2009-2015)}

The WFD RBMPs published in 2009 (Fig. 2) varied significantly in size, and they presented very different challenges. A review of some of these first-round RBMPs suggested that there was a similar diversity in the extent to which these plans recognized the important role that sediment-related issues play in river systems in terms of both quantity and quality. SedNet therefore organized a second round table discussion on 6 and 7 October 2009 in Hamburg, Germany. This was an opportunity for national experts involved in sediment management and WFD implementation to meet and exchange experiences, to identify gaps in knowledge/understanding, and to draw up recommendations for practical ways to include sediment management better in the implementation of the WFD in the future when relevant to do so. The other objectives of the round table were as follows: (1) to develop a better understanding of situations in which sediment issues are already addressed in some RBMPs and the interests behind their inclusion; (2) to discuss the extent to which sediment management is linked to WFD objectives and to identify those aspects which may not be adequately covered by the WFD remit; and (3) to identify opportunities and make recommendations for the better inclusion of relevant sediment issues in the second round of RBMPs. The thirty participants at the round table came from river commissions, government bodies, water agencies, port authorities, research institutes, consultancies, NGOs, and SedNet, and they represented river basins from across 
Europe: Douro, Ebro, Danube, Sava, Drava/Mura, Elbe, Rhine, Scheldt, and the Anglian River Basin District (SedNet 2010).

In the context of this second round table, the participants collated and submitted information about the implementation of the WFD in the river basins with which they were associated. This survey revealed that different approaches, on a wide variety of scales, had been taken to dealing with sediment issues in the RBMPs reviewed. However, it also revealed a range of important links between sediment and water management and highlighted the potential benefits associated with improving the inclusion of certain sediment issues in a holistic approach to practical management. Those providing information were also asked to state the reasons for this variation and why they thought sediment issues had not been considered more thoroughly or consistently. A variety of reasons were put forward, but the most common were as follows: (1) the complexity of sediment issues, a lack of data, knowledge, or system understanding; (2) the lack of clear target values or guidelines; and (3) the fact that sediments are not considered a priority in the WFD.

Many respondents also suggested that including sediment management in RBMPs would be a promising approach in the future but that it is important to recognize that there are other legitimate approaches, for example, in the context of navigation or flood risk management planning. RBMPs will therefore not be the only solution for effective sediment management (SedNet 2010).

The second round table concluded with key messages in line with the messages in the 2004 SedNet booklet (Salomons and Brils 2004): "Sediment is an essential, integral and dynamic part of our river basins. Where human activities interfere with sediment quantity or quality, sediment management becomes necessary. It therefore seems logical to seek to realize relevant opportunities to link sediment management to river basin management and, where appropriate, to the WFD" (SedNet 2010).

It was also concluded that it is self-evident that good environmental status in a water body also requires good sediment status and that more knowledge is required to enable a proper understanding of the various connections between sediment management and WFD objectives. Win-win solutions achieving both WFD and sediment management objectives are often possible. Furthermore, the round table recommended the development of guidance about how to include sediment management in river basin planning. Short-term actions could include the collation of case studies and the preparation of guidance to help sediment managers and river basin managers understand the links between sediment and water, to prepare sediment management plans, and to promote the inclusion of sediment management issues in the second round of RBMPs (SedNet 2010).
Inspired by the work done so far by SedNet, German and Czech Republic sediment experts elaborated and finalized the ICPER (International Commission for the Protection of the Elbe River) sediment management concept for the Elbe region (IKSE 2014). The concept includes proposals for good sediment management practice, as well as recommendations for actions targeting hydromorphology, quality, and navigation (Heininger et al. 2015).

The ICPER sediment management concept recommendations were taken on board in the second RBMP (2015-2021) for the Elbe (IKSE 2015), providing for the first time an example of the full inclusion of sediment management in a RBMP and therefore for the opening of the policy window.

\subsection{Towards the second problem and policy window (2015-2021)}

In response to the inclusion of sediment in the Elbe RBMP, SedNet, the International Commission for the Protection of the Danube River (ICPDR) and ICPER jointly organized a third round table discussion. The ICPER organizes and coordinates international cooperation in the Elbe catchment to safeguard all relevant forms of water use, achieve the most natural ecosystem possible, and reduce the pollution of the North Sea by the Elbe River. The ICPDR works to ensure the sustainable and equitable use of waters and freshwater resources in the Danube River Basin. The ICPDR is also the platform for the implementation of all transboundary aspects of the European WFD (EC 2000) and European Floods Directive (EC 2007). The round table discussion was entitled "Bringing Together Experiences in Sediment Management Concepts - Elbe meets Danube," and it took place between 8 and 9 November 2016 in Budapest, Hungary. The aim was to establish exchanges of experiences between the Danube and Elbe river basins and SedNet about the inclusion of sediment management in river basin management. However, representatives of other European river basins were also invited, and a representative of the International Sava River Basin Commission (ISRBC) and a representative of the International Commission for Protection of the Rhine (ICPR) accepted the invitation. In addition to the representatives of these four river basins, the round table was also attended by scientists, port managers, consultants, and water policy officers from the national to the European (EC Directorate General Environment-EC DG Env-Water Unit) policy levels.

Given the outcome of the discussions, the SedNet steering group decided not to produce another-third - round table discussion document. The steering group drafted a policy brief in the conviction that it would have more impact (SedNet 2017). The key message in the policy brief was in line with previous communications from SedNet: "European water policy objectives will only be achieved by also integrating 
sediment in River Basin Management Planning." Furthermore, the brief states: "Underpinned by the work of SedNet, the Elbe provides now for the first time an example on how to integrate sediment. SedNet is delighted with this milestone and is happy to share its experience with other European river basins." "The relevance of sediments for achieving fundamental management goals in river basins is obvious. However, the perceived complexity often hinders the full integration of sediment issues into river basin management." The first copy of the SedNet policy brief was handed over during the 10th International SedNet conference (14-17 June, Genoa, Italy) to the same member of the EC DG Environment Water Unit who participated in the third round table discussion. The brief was widely disseminated after the conference, primarily through the SedNet secretariat's email list, reaching close to 2000 sediment professionals in science, policy, and practice around the world.

Following on from the third round table discussion and the policy brief, SedNet was invited to present the brief at the meeting of the WFD Common Implementation Strategy (CIS) working group (WG) on Ecological Status (ECOSTAT) on 10 October 2017 in Ispra, Italy. Since then, SedNet has continued to attend the WG ECOSTAT meetings, contributing its experience and points of view. During the same period, SedNet was also waiting for the outcome of its application to become an official member of the WFD CIS Strategic Coordination Group (SCG) as an environmental NGO. That application was approved on 18 September 2019. The role of the SCG is to coordinate the different CIS WGs and activities such as work in the pilot river basins as part of a shared strategy (EC 2018).

ECOSTAT felt that there was a need to conduct further explorations of the possible sediment management aspects related to WFD implementation. As a result, ECOSTAT worked with SedNet on the joint organization of an ECOSTAT sediment workshop on 1-2 April 2019 in Dubrovnik, Croatia. The workshop brought together WFD experts, sediment experts, ecologists, regulators, and stakeholder group representatives with the aim of exploring and acquiring information about the following issues: (1) why sediment management is of relevance to the WFD; (2) how the sediment management issues can be addressed in WFD RBMPs; (3) good practice with respect to the inclusion of sediment management and WFD Good Ecological Status (GES)/Good Ecological Potential (GEP); and (4) obstacles to the further integration of sediment in RBMPs and how to overcome them.

The key ECOSTAT sediment workshop outcome was consensus among workshop participants that there is a clear need to provide further guidance on how both sediment quantity and quality should be managed to support the achievement of the WFD objectives. Participants also agreed that the guidance should not be simple because it needs to address the complexity inherent in the sedimentary system in order to facilitate progress towards the goal of improved sediment management in accordance with the WFD. Contributions from outside ECOSTAT, including experts from established networks such as SedNet, should therefore be sought to inform the development of the guidance. Furthermore, sediment management issues are cross-cutting and relevant to other working groups under the WFD (such as the CIS WG Chemicals) and other European directives such as the Habitats Directive (ECC 1992), Floods Directive (EC 2007), Marine Strategy Framework Directive (EC 2008), and Birds Directive (EC 2009). Cooperation with other policy areas is therefore required to ensure that sediment management issues are adequately addressed (EC 2019a).

Following up on this recommendation, ECOSTAT submitted a proposal to the WFD CIS SCG for the inclusion of sediment in the 2019-2021 ECOSTAT work program and specifically for the drafting of a WFD CIS sediment document. That proposal was approved by the SCG-and also by the European Water Directors - but the WFD SCG meeting of 13 November 2019 agreed that the decision about whether the document will be published as a CIS Guidance Document or as a Technical Report needs to be made by the SCG and the Water Directors. It was therefore proposed that ECOSTAT should start work on the sediment document and that a formal decision about its status should be made once a first draft is available for review (EC 2019b).

As this JSS paper is being finalized, the status of the CIS sediment document is that the experts involved in drafting have been nominated by the European Member States and that they will work with other experts, including experts from the SedNet steering group. The drafting of the document began in mid-2020, and completion of the document will be required before the end of the current work program and therefore no later than the end of 2021. The 2019 ECOSTAT sediment workshop also delivered the outline and initial ideas for the content of the document. This content has now been allocated to four sub-groups, each of which includes relevant experts who will jointly produce the following chapters: (1) catchment scale analysis; (2) sediment quantity; (3) sediment contamination; and (4) integrated sediment management planning. Each chapter is expected to consist of approximately twenty pages. The focus will be on key messages, with references to other documents/reports for more precise information. In addition to the main text of the document, a library of existing information (publications, reports, guidance, management plans and case studies) will be set up and maintained.

As stated in Section 3.1, completion of the CIS sediment document is expected in 2021, and it will then be used by the RBMP drafters. However, the document will not be produced 
in time to serve as a basis for the third RBMP since that drafting process is now being completed (in mid-2020).

\subsection{Looking ahead to the third policy window (2021- 2027)}

The 2021 CIS sediment document will be produced in time to serve as a basis for the drafting of the fourth round of RBMPs, which will have to be approved in 2027, with implementation beginning in the same year. There are positive signals suggesting that other RBMPs - in addition to the one for the Elbe-will include sediment fully by 2027 . At present, as the end of the second period of implementation for the WFD RBMPs approaches, the condition of European water bodies continues to be poor (EEA 2018; EC 2019c). There is therefore an urgent need to improve RBMPs, for example, by fully including sediment management. The Water Fitness Check was published on 12 December 2019 (EC 2019c). This fitness check is a comprehensive evaluation of European water policy including the WFD. It assesses whether these policies are fit for purpose. It identifies chemicals as a key area where there is room for improvement and better results. It refers on several occasions to the binding and accumulation of chemicals (in other words, pollutants) in sediments and to the monitoring of levels in sediments. However, the fitness check also draws attention to several other sediment- and water-related issues. It links sediments to hydromorphology by stating that water and sediments interact at different scales and shape the physical environment, determining physico-chemical processes, and providing a physical habitat for the biota. Hydromorphology is a term used to describe the hydrological and geomorphological characteristics (including continuity) of rivers, lakes, and coastal and transitional waters, including the underlying processes from which they result. Hydromorphological alteration is one of the key obstacles to the achievement of the WFD objectives. Furthermore, the fitness check states that "sediments are transported from river basins to marine areas, but in many river basins there are insufficient or no management measures for sediments at river basin level. This can be an issue for marine habitats when the supply of sediment is insufficient to prevent or compensate for coastal erosion." Some stakeholders, in particular from the navigation sector, stated their concern in the fitness check that the interplay between the WFD and Marine Strategy Framework Directive (EC 2008) does not function well enough with respect to sediment management.

This fitness check is the first EC water policy-related document to draw attention so clearly to sediment management as an issue to be included with the aim of improving the effectiveness of achieving European water policy objectives such as those of the WFD. It can therefore be expected that there will be much more interest (or perceived urgency) among European makers of water policy with respect to the inclusion of sediment management in WFD RBMPs. In combination with the CIS sediment document to be published in 2021, this makes it significantly more likely that sediment will be included in the fourth round of RBMPs in 2027.

\section{Conclusions}

The relevance of sediment management for the achievement of European WFD policy goals (good chemical and good ecological status) in river basins has been obvious to SedNet since its establishment in 2000. SedNet has persistently drawn attention to the inclusion of sediment in WFD RBMPs. However, it was not until 2015 that the Elbe became the first European river basin to include sediment management fully in the relevant RBMP (IKSE 2015). That was done on the basis of the SedNet-inspired ICPER sediment management concept (IKSE 2014). The 2021 WFD CIS sediment document, which is currently being drafted with the help of SedNet experts, as well as the focus on sediment in the Water Fitness Check (EC 2019c), makes it significantly more likely that sediment will be included in the updates of WFD RBMPs in the near future. SedNet will continue, and, as stated in its 2017 policy brief, it will be available to offer support for the integration of sediment in river-basin or, even better, the entire river-sea system management by sharing its extensive experience relating to sediment and sediment management.

Acknowledgments I would like to thank Pete Thomas for his help to improve the English writing and the two anonymous referees for their helpful comments which greatly improved the structure and narrowed the scope of the manuscript. Furthermore, there are simply too many other individuals to thank personally, and there is a danger that I may overlook someone unintentionally. I therefore wish to thank all my SedNet friends deeply and sincerely, several of whom have been on board since SedNet was established in 2000. Working with large numbers of new friends who joined us along the way, we have kept SedNet going. SedNet is unique in the way it brings together sediment scientists, policymakers, managers, and practitioners throughout Europe and beyond. What united us from the very beginning was our shared vision of sediment and sediment management. That vision has evolved slightly over the years, but there has been no fundamental change: Sediment is essential for the health of any riversea system, and sediment management becomes necessary wherever humans intervene in that system.

Open Access This article is licensed under a Creative Commons Attribution 4.0 International License, which permits use, sharing, adaptation, distribution and reproduction in any medium or format, as long as you give appropriate credit to the original author(s) and the source, provide a link to the Creative Commons licence, and indicate if changes were made. The images or other third party material in this article are included in the article's Creative Commons licence, unless indicated otherwise in a credit line to the material. If material is not included in the article's Creative Commons licence and your intended use is not permitted by statutory regulation or exceeds the permitted use, you will need to obtain permission directly from the copyright holder. To view a copy of this licence, visit http://creativecommons.org/licenses/by/4.0/. 


\section{References}

Apitz S, Heise S (2005) From the SETAC-EU/SedNet advisory group on sediments. J Soils Sediments 5:253-254. https://doi.org/10.1065/ jss2005.11.003

Barceló D, Petrovic M, de Deckere E, Bakker JF, Scrimshaw M, Stegemann J, Kowalewska G, Heininger P, Vale C, Hansen PD, Belzunce Segarra MJ, Parker A, Poulsen V, Manz W, Blasco J, DelValls CA (2004) Synthesis of the SedNet work package 3 outcomes. J Soils Sediments 4:223-224. https://doi.org/10.1007/ BF02991116

Blum WEH (2002) The new association between JSS and IUSS. J Soils Sediments 2:106-107. https://doi.org/10.1007/BF02988459

Bortone G, Arevalo E, Deibel I, Detzner HD, de Propris L, Elskens F, Giordano A, Hakstege P, Hamer K, Harmsen J, Hauge A, Palumbo L, van Veen J (2004) Synthesis of the SedNet work package 4 outcomes. J Soils Sediments 4:225-232. https://doi.org/10.1007/ BF02991117

Brils J (2001) SedNet: demand-driven, European sediment research network. J Soils Sediments 1:204. https://doi.org/10.1007/ BF02987725

Brils J (2002a) The SedNet mission. J Soils Sediments 22:2-3. https://doi. org/10.1007/BF02991243

Brils J (2002b) SedNet corner (demand-driven, European sediment research network). J Soils Sediments 2:164. https://doi.org/10.1007/ BF02991033

Brils J (2003a) SedNet corner (demand-driven, European sediment research network). J Soils Sediments 3:4. https://doi.org/10.1007/ BF02989458

Brils J (2003b) SedNet corner (European sediment research network). J Soils Sediments 3:267-268. https://doi.org/10.1007/BF02988688

Brils J (2004a) SedNet corner (demand-driven, European sediment research network). J Soils Sediments 4:72-73. https://doi.org/10. 1007/BF02991047

Brils J (2004b) Three years of SedNet. J Soils Sediments 4:216-217. https://doi.org/10.1007/BF02991113

Brils J (2005a) Commission will continue its efforts to overcome the lack of knowledge on sediment quality in the EU. J Soils Sediments 5: 48-49. https://doi.org/10.1065/jss2005.01.002

Brils J (2005b) 2005, A transition year for SedNet. J Soils Sediments 5: 70. https://doi.org/10.1065/jss2005.02.002

Brils J (2012) Urgency and timing: key-pillars of the science-policy bridge. Invited presentation at the EC DG Environment organized green week event 'the water challenge: every drop counts', Brussels, 22-25 may 2012

Brils J, de Deckere E (2003) SedNet - an evolving network aimed at sustainable sediment management. J Soils Sediments 3:127-128. https://doi.org/10.1007/BF02988655

EC (2000) Directive 2000/60/EC of the European Parliament and of the council establishing a framework for the community action in the field of water policy (Water Framework Directive). European Commission (EC), Brussels

EC (2007) Directive 2007/60/EC of the European Parliament and of the council of 23 October 2007 on the assessment and management of flood risks (floods directive). European Commission (EC), Brussels

EC (2008) Directive 2008/56/EC of the European Parliament and of the council of 17 June 2008 establishing a framework for community action in the field of marine environmental policy (Marine Strategy Framework Directive). European Commission (EC), Brussels

EC (2009) Directive 2009/147/EC of the European Parliament and of the council of 30 November 2009 on the conservation of wild birds (codified version)(birds directive). European Commission (EC), Brussels

EC (2018) Rules of procedure for the strategic co-ordination group under the Water Framework Directive and Floods Directive Common
Implementation Strategy (Document endorsed by Water Directors in Sofia in June 2018). European Commission (EC), Brussels

EC (2019a) Workshop Summary Report - ECOSTAT workshop: sediment management in support of achieving GEP, $1^{\text {st }}-2^{\text {nd }}$ April 2019, Hotel Dubrovnik Palace, Dubrovnik, Croatia. European Commission (EC), Directorate-General Environment, Directorate C - Quality of Life, ENV.C.1 - Clean Water, Brussels, Belgium

EC (2019b) Minutes of the meeting of the strategic co-ordination group for the WFD Common Implementation Strategy, 13 November 2019, Brussels, Belgium. European Commission (EC), Directorate-General Environment, Directorate C - Quality of Life, ENV.C.1 - Clean Water, Brussels, Belgium

EC (2019c) Fitness Check of the Water Framework Directive and the Floods Directive - Commission Staff Working Document Fitness Check. Brussels, 10.12.2019 SWD(2019) 439 final. European Commission (EC), Directorate-General for Environment, Brussels, Belgium

ECC (1992) Council directive 92/43/EEC of 21 may 1992 on the conservation of natural habitats and of wild fauna and flora (habitats directive). European Economic Community (ECC), Brussels

EEA (2018) European waters Assessment of status and pressures 2018. EEA report no 7/2018. European Environment Agency (EEA), Copenhagen

Förstner U (2002) Sediments and the European Water Framework Directive. J Soils Sediments 2:54. https://doi.org/10.1007/ BF02987869

Gandrass J, Salomons W, Foerstner U (Eds.) (2000) River sediments and related dredged material in Europe scientific background from the viewpoints of chemistry, ecotoxicology and regulations. Workshop report - 3-5 April 2000, GKSS research Centre, Geesthacht

Heininger P, Keller I, Quick I, Schwartz R, Vollmer S (2015) Sediment management on river-basin scale: the river Elbe. In: Heininger P, Cullmann J (eds) Sediment Matters. Springer International, pp 201247

Heise S (2003) SedNet-working group on risk management (WG 5). J Soils Sediments 3:129-131. https://doi.org/10.1007/BF02988656

Heise S, Apitz SE, Babut M, Bergmann H, den Besten P, Ellen GJ, Joziasse J, Katsiri A, Maaß V, Oen A, Slob A, White S (2004) Synthesis of the SedNet work package 5 outcomes. J Soils Sediments 4:233-235. https://doi.org/10.1007/BF02991118

Hollert H, Heise S, Ahlf W (2005) Formation of a SETAC Europe/ SedNet-advisory group on sediments at the SETAC Europe annual meeting 2005 in Lille. Join together for sediments in research and application. J Soils Sediments 5:192. https://doi.org/10.1065/ jss2005.08.005

IKSE (2014) Sedimentmanagementkonzept der IKSE - Vorschläge für eine gute Sedimentmanagmentpraxis im Elbegebiet zur Erreichung überregionaler Handlungsziehle. Internationale Kommission zum Schutz der Elbe (IKSE), Magdeburg, Germany

IKSE (2015) Internationale Bewirtschaftungsplan für die Flussgebietseinheit Elbe - Teil A Aktualisiering 2015 für den Zeitraum 2016-2021. Internationale Kommission zum Schutz der Elbe (IKSE), Magdeburg, Germany

Kingdon JW (1995) Agendas, alternatives, and public policies. Longman, New York

Köthe H (2003) Existing sediment management guidelines: an overview. J Soils Sediments 3:139-142. https://doi.org/10.1065/jss2003.08. 082

Netzband A (2004) Central dredging association (CEDA): position papers river basin sediment management from the viewpoint of dredging stakeholders. J Soils Sediments 4:236-238. https://doi.org/10. 1007/BF02991119

Netzband A (2007) Sediment management: an essential element of River Basin Management Plans. J Soils Sediments 7:117-132. https://doi. org/10.1065/jss2007.02.212 
Owens PN, Xu Z (2020) Journal of soils and sediments: the first 20 years. J Soils Sediments 20:595-598. https://doi.org/10.1007/s11368-02002566-7

Owens PN, Apitz S, Batalla R, Collins A, Eisma M, Glindemann H, Hoornstra S, Köthe H, Quinton J, Taylor K, Westrich BT, White S, Wilkinson H (2004) Synthesis of the SedNet work package 2 outcomes. J Soils Sediments 4:219-222. https://doi.org/10.1007/ BF02991115

Salomons W, Brils J (2004) Contaminated Sediments in European River Basins. SedNet

SedNet (2002) Expression of interest (EoI) for a network of excellence (NoE) on management of European sediment resources (SedNetexcel). J Soils Sediments 2:55. https://doi.org/10.1007/BF02987870

SedNet (2003a) First announcement: SedNet workshops. J Soils Sediments 3:5. https://doi.org/10.1007/BF02989459

SedNet (2003b) Strategy paper. J Soils Sediments 3:63-64. https://doi. org/10.1007/BF02991065

SedNet (2003c) River basin cases. J Soils Sediments 3:64. https://doi.org/ 10.1007/BF02991067
SedNet (2003d) Conference announcement. J Soils Sediments 3:108. https://doi.org/10.1007/BF02991076

SedNet (2007) Sediment Management - an essential element of River Basin Management Plans, Report on the SedNet Round Table Discussion. Venice, 22-23 November 2006. SedNet

SedNet (2010) Integration of Sediment in River Basin Management. Report on the $2^{\text {nd }}$ SedNet Round Table Discussion. Hamburg, 6-7 October 2009. SedNet

SedNet (2017) Effective river basin management needs to include sediment - SedNet policy brief. SedNet

Vellinga T (2004) From dredged material management to sediment management. J Soils Sediments 4:215. https://doi.org/10.1007/ BF02991112

Publisher's note Springer Nature remains neutral with regard to jurisdictional claims in published maps and institutional affiliations. 